\title{
Study of sorption systems for application on low-emission fishing vessels Valeria Palomba ${ }^{\text {a, b, }}$, Marcello Aprile ${ }^{c}$, Mario Motta ${ }^{c}$, Salvatore Vasta ${ }^{a}$

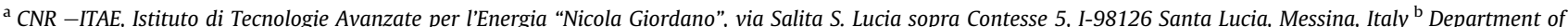 Engineering, University of Messina, C.da di Dio, 98166 Messina, Italy \\ ${ }^{\mathrm{c}}$ Department of Energy, Politecnico di Milano, via Lambruschini 4, Milano, Italy
}

\begin{abstract}
Waste-heat driven refrigeration technology represents a promising alternative for food preservation on-board, that could help reducing pollutant emissions and, at the same time, limiting fuel consumption. Aim of the present work is the assessment of possible benefits arising from the use of thermally driven systems, with focus on two technologies: absorption and adsorption. A dynamic simulation of the whole waste heat recovery system and the sorption refrigerators has been performed. For the modelling of the thermally driven chillers, experimental data from two prototypes have been employed. The results show that, for a cooling load typical of the Italian fishing fleet, fuel savings up to $1600 \mathrm{~kg} / \mathrm{y}$ can be achieved, corresponding to 3 ton/ $\mathrm{y}$ of avoided $\mathrm{CO}_{2}$ emissions. Moreover, for bigger vessels with $10 \mathrm{~kW}$ cooling load needed, up to 7 times higher fuel savings can be obtained.
\end{abstract}

\section{Introduction}

In 2012, international maritime fleet has been responsible for the emission of about 900 million tonnes of $\mathrm{CO}_{2}$ [1] and, despite the efforts devoted to environmental care, a relevant decreasing trend cannot be identified. Moreover, suggested scenarios up to 2050 predict an increase in the total amount of GHG emitted, because of a higher transportation request [1]. Among these, about 10,000 tonnes are due to refrigerant losses: even though some ozone depleting refrigerants have been replaced, the most commonly used ones still present GWP higher than 1000 [1]. Moreover, 25\% of total gaseous emissions are associated to the whole operation of HVAC and refrigeration systems on board [2], because of the additional fuel consumption due to the mechanical power required by the compressors. In such a context, the utilization of waste heat and a general better exploitation of energy sources on board are of primary importance. One of the main and still underexploited possible energy sources is heat recovery from the main engine: despite a lot of efforts $[3,4]$ and methods suggested, the main topics for research is still the optimization of the Diesel engine. However,

\footnotetext{
* Corresponding author. CNR -ITAE, Istituto di Tecnologie Avanzate per l'Energia “Nicola Giordano", via Salita S. Lucia sopra Contesse 5, I-98126 Santa Lucia, Messina, Italy.

E-mail address: valeria.palomba@itae.cnr.it (V. Palomba).
}

as discussed in Ref. [4], more than $30 \%$ of waste heat from exhaust or coolant water of the main mover of a ship is recoverable, at temperatures up to $180^{\circ} \mathrm{C}$.

Different methods have been proposed for the utilization of recovered heat, including space heating [5], application of ORC cycles [6], and desalination [4]. Space heating and cooling through sorption technologies has also been the central topic of various studies. Fernandez-Seara et al. [7] have developed a heat recovery system, consisting in a generator and an economizer, to provide thermal energy input to an absorption chiller. Results showed that energy recovered from the engine of a ship is suitable for the application considered, as temperature level and heat available exceed those required. Ouadha et al. [8] have carried out a ther-modynamic analysis of an ammonia-water system, considering also the energy balance for a marine Diesel, demonstrating that this is able to provide sufficient waste heat to drive the absorption chiller. Cao et al. [9] developed a TRNSYS model to simulate an absorption chiller used for space cooling in a cargo ship in Miami conditions, finding out that the system is able to provide comfort conditions in the examined route. The same authors, in Ref. [10], have developed a TRNSYS model to compare the absorption system of a baseline VCC one, performing also a payload and economic analysis that have demonstrated the feasibility of such systems. Ezgi [11] performed a thermodynamic analysis on a $\mathrm{LiBr} /$ water system for both space heating and cooling on a naval surface ship driven by waste 


\section{Nomenclature}

$\begin{array}{ll}\text { A } & \text { heat exchange area, } \mathrm{m}^{2} \\ \mathrm{E} & \text { energy, } \mathrm{kWh} \\ \mathrm{P} & \text { power, } \mathrm{kW} \\ \Delta \mathrm{CO}_{2} & \text { avoided } \mathrm{CO}_{2} \text { emission, } \mathrm{kg} \\ \mathrm{m} & \text { mass, } \mathrm{kg} \\ \mathrm{U} & \text { overall heat transfer coefficient, } \mathrm{W} / \mathrm{m}^{2} \mathrm{~K}\end{array}$

$\begin{array}{ll}\begin{array}{l}\text { Abbreviations } \\ \text { chw }\end{array} & \text { chilled water, }{ }^{\circ} \mathrm{C} \\ \text { cw } & \text { cooling water, }{ }^{\circ} \mathrm{C} \\ \text { COP } & \text { coefficient of performance } \\ \text { EES } & \text { electricity energy savings, kWh } \\ \text { el } & \text { electric } \\ \text { EGE } & \text { exhaust gas economizer } \\ \text { FS } & \text { fuel savings, kg } \\ \text { GHG } & \text { greenhouse gas } \\ \text { GRT } & \text { gross registered tonnage } \\ \text { GWP } & \text { global warming potential } \\ \text { HVAC } & \text { heating, ventilation and air conditioning } \\ \text { HT } & \text { desorption temperature, }{ }^{\circ} \mathrm{C}\end{array}$

heat from the engine, showing that the seawater cooled system not only meets the actual heating and cooling loads of the examined ship, but also provides more.

Refrigeration represents a crucial sector as well, since it heavily demanding in terms of fuel consumption and determining high amount of GHG emissions [2,12]. Focus of the research for refrigeration on board has been the study on icemakers for the production of flake ice. Wang et al. [14] developed a carbon/methanol adsorption icemaker suitable to be driven by waste heat for the production of flake ice. Wang et al. [15] developed a heat-pipe adsorber with a compound sorbent for application in icemakers on board. Recently, Shi et al. [16] studied an absorption chiller suitable for refrigeration purposes and for driving circuits with lower temperatures than a traditional single effect absorption chiller. In Ref. [17], Lu and Wang compared two adsorption re-frigerators and an absorption refrigerator for waste-heat driven applications, by experimental measurements, showing that ammonia/water absorption presents the best performance.

A summary of the studies available in literature regarding the application of sorption technology to the marine sector is shown in Table 1, where the application field and type of study is described.

As highlighted from such a literature survey, the studies in literature focus almost solely on air conditioning. On the contrary, preservation of food on-board has not been extensively considered. The few attempts to do so have been directed towards the development of ice-makers. Instead, the refrigeration of the cold rooms has not been considered up to now. The peculiarity of the present work is the study of sorption devices for food preservation below 0 ${ }^{\circ} \mathrm{C}$ by applying the performance data of two experimentally measured systems under the boundary conditions of marine refrigeration. Moreover, the study focuses on two different technologies: ammonia-water absorption and ethanol-activated carbon adsorption. On the one hand, ammonia-water absorption is a wellproven commercially available technology that has been applied in a variety of fields for refrigeration purposes, showing values of thermal COP above 0.5 with a driving temperature of approximately $180{ }^{\circ} \mathrm{C}$. Thus, analysing the potential of this technology can provide the basis for comparison for alternative sorption

$\begin{array}{ll}\text { MT } & \text { medium temperature, }{ }^{\circ} \mathrm{C} \\ \text { LHV } & \text { lower heating value, } \mathrm{kWh} / \mathrm{kg} \\ \text { LT } & \text { low temperature, }{ }^{\circ} \mathrm{C} \\ \text { NTU } & \text { number of Transfer Units } \\ \text { ORC } & \text { organic Rankine cycle } \\ \text { PLR } & \text { part load ratio } \\ \text { th } & \text { thermal } \\ \text { VCC } & \text { vapour compression chiller } \\ & \\ \text { Greek } & \text { symbols } \\ \alpha & \text { leakage rate } \\ \beta & \text { scaling factor } \\ \varepsilon & \text { heat exchanger effectiveness } \\ \delta & \text { scaled value } \\ \Delta & \text { displacement, } \mathrm{t} \\ \eta & \text { efficiency } \\ \eta_{\text {co2 }} & \text { national } \mathrm{CO}_{2} \text { emission factor, } \mathrm{t} / \mathrm{MWh} \\ & \\ \text { Subscripts } \\ \text { gen } & \text { generator } \\ \text { ref } & \text { reference } \\ \mathrm{s} & \text { sorption }\end{array}$

technologies that are less mature. Moreover, even though the application of ammonia refrigeration is consolidated in other application areas, on-board refrigeration has not been fully analysed or exploited and, as shown in Table 1, the majority of studies on absorption technology on-board deal with $\mathrm{LiBr} /$ water chillers. On the other hand, ethanol-activated carbon adsorption is still under development, and despite lower thermal COPs it can be driven by lower temperatures $\left(<90{ }^{\circ} \mathrm{C}\right)$. With respect to other working pairs, activated carbon-ethanol has a great potential for food preservation applications, since ethanol is non-toxic.

For such reasons, there is a need to study how these two technologies can fit in the application of interest for this work, in order to assess the benefits obtainable as well as the open issues still. To this aim, in the present work, TRNSYS environment has been chosen for the modelling of the two waste-heat driven refrigeration systems, including the definition of heat recovery system, auxiliary pumps, and control strategy, in order to assess their performance. The absorption and the adsorption chillers, which represent the core of the two systems under investigation, have been modelled using experimental data of two already existing prototypes and applying scaling rules in order to match the refrigeration capacity required by the application. Subsequently, an energy and environmental analysis has been performed, comparing the sorption systems to a traditional VCC one. Finally, a sensitivity analysis was realised, in order to generalise the obtained results to other scenarios.

\section{The case study}

Reference application for the developed analysis has been the Italian fishing fleet, with particular focus on the vessels stationed in Mazara del Vallo, which represents the biggest fishing port in Italy [18]. Among the fishing boats available, the case corresponding to the most diffused types of vessels has been considered [19], i.e. a vessel with GRT about 20 and engine power of $195 \mathrm{~kW}$.

For the vessels under investigation, the traditional refrigeration system on board is mainly composed of four components [20]: 
Table 1

Literature studies regarding the application of sorption chillers to the marine sector.

\begin{tabular}{|c|c|c|c|c|c|c|}
\hline Reference & Application field & Technology & Chiller & Type of study & $\begin{array}{l}\text { Comparison with other } \\
\text { technologies }\end{array}$ & Analysis of heat recovery system \\
\hline [7] & Heat recovery & Absorption & $\mathrm{NH}_{3} / \mathrm{H}_{2} \mathrm{O}$ & $\begin{array}{l}\text { Mathematical } \\
\text { modelling }\end{array}$ & No & Yes, design of economizer \\
\hline [8] & Space cooling & Absorption & $\mathrm{NH}_{3} / \mathrm{H}_{2} \mathrm{O}$ & $\begin{array}{l}\text { Thermodynamic } \\
\text { modelling }\end{array}$ & No & No \\
\hline [9] & Space cooling & Absorption & $\mathrm{H}_{2} \mathrm{O} / \mathrm{LiBr}$ & Dynamic modelling & VCC & Yes, selection of components \\
\hline [10] & Space cooling & Absorption & $\mathrm{H}_{2} \mathrm{O} / \mathrm{LiBr}$ & Dynamic modelling & VCC & Yes, selection of components \\
\hline [11] & $\begin{array}{l}\text { Space heating } \\
\text { and cooling }\end{array}$ & Absorption & $\mathrm{H}_{2} \mathrm{O} / \mathrm{LiBr}$ & $\begin{array}{l}\text { Thermodynamic } \\
\text { modelling }\end{array}$ & VCC & $\begin{array}{l}\text { Yes, selection of properties of the } \\
\text { exhaust heat exchanger }\end{array}$ \\
\hline [13] & Space cooling & Adsorption & Water/hybrid adsorbent & $\begin{array}{l}\text { Experimental testing of } \\
\text { refrigerator }\end{array}$ & No & No \\
\hline [14] & Ice-making & Adsorption & Methanol/activate carbon & $\begin{array}{l}\text { Experimental testing of } \\
\text { refrigerator }\end{array}$ & No & No \\
\hline [15] & Ice-making & Adsorption & Ammonia/compound adsorbent & $\begin{array}{l}\text { Experimental testing of } \\
\text { refrigerator }\end{array}$ & No & No \\
\hline [16] & Refrigeration & Absorption & NA & $\begin{array}{l}\text { Thermodynamic } \\
\text { analysis of the cycle }\end{array}$ & No & No \\
\hline [17] & Refrigeration & $\begin{array}{l}\text { Adsorption and } \\
\text { absorption }\end{array}$ & $\begin{array}{l}\text { Ammonia/compound adsorbent } \\
\text { and ammonia/water }\end{array}$ & $\begin{array}{l}\text { Experimental testing of } \\
\text { refrigerators }\end{array}$ & No & $\begin{array}{l}\text { No, but design consideration are } \\
\text { made }\end{array}$ \\
\hline
\end{tabular}

- A $10 / 15 \mathrm{~m}^{3}$ cell for rapid freezing of fish, employing a direct expansion system for refrigeration of fish to $-20^{\circ} \mathrm{C}$ in less than $3 \mathrm{~h}$;

- A $40 / 50 \mathrm{~m}^{3}$ cell for storage of frozen fish at temperatures of about $-4{ }^{\circ} \mathrm{C}$;

- A $40 / 50 \mathrm{~m}^{3}$ cell for storage of fresh fish at temperatures of +2 / $+4{ }^{\circ} \mathrm{C}$;

- An icemaker for the production of ice flakes.

All of the refrigeration systems employ a single screw-type compressor, driven by the electricity produced by the main generator of the boat and having R422a as refrigerant. For both the frozen fish and fresh fish cell, in the traditional system, a cooling coil with total surface of about $40 \mathrm{~m}^{2}$ is generally employed. For the present analysis, only the replacement of the traditional vapour compression system for the frozen fish storage cell has been considered. A schematic layout of the two proposed systems is shown in Fig. 1: in both cases, the thermally driven sorption chiller represents the main unit for chilled water production, with seawater as cooling medium for the heat rejection system. The two systems differ for the driving circuit: in the case of absorption chiller, an economizer for the recovery of waste heat from exhaust has been considered, since the absorption chiller currently employed requires a driving temperature between 180 and $210^{\circ} \mathrm{C}$. Instead, the adsorption chiller is driven by the heat recovered from the cooling water circuit of the main engine of the ship, since the heat required as input shall be at much lower temperatures $\left(70-90^{\circ} \mathrm{C}\right)$. A more detailed layout of the systems is shown in Fig. 2, where all the most relevant thermal and hydraulic components that have been included in the simulations are visible. The component indicated as "heat recovery system" is the heat exchanger used to recover heat from either the exhaust gases or the cooling water of the engine, depending on the type of chiller used absorption or adsorption respectively. Accordingly, lines 1 and 2 employ either diathermic oil or water.

Considering also the specific situation of the Italian fishing fleet, 2 scenarios have been simulated, corresponding to different load profiles for the cold room [21]. In both cases, the amount of fish introduced during the day is the same, and corresponds to $600 \mathrm{~kg}$,

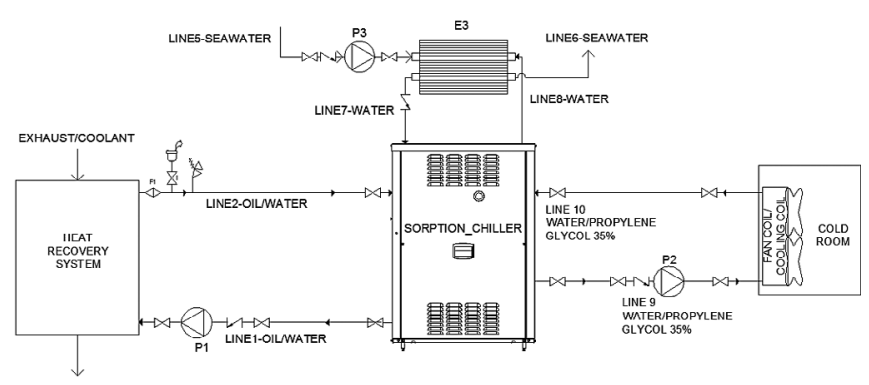

Fig. 2. Detailed layout of the heat-driven systems.

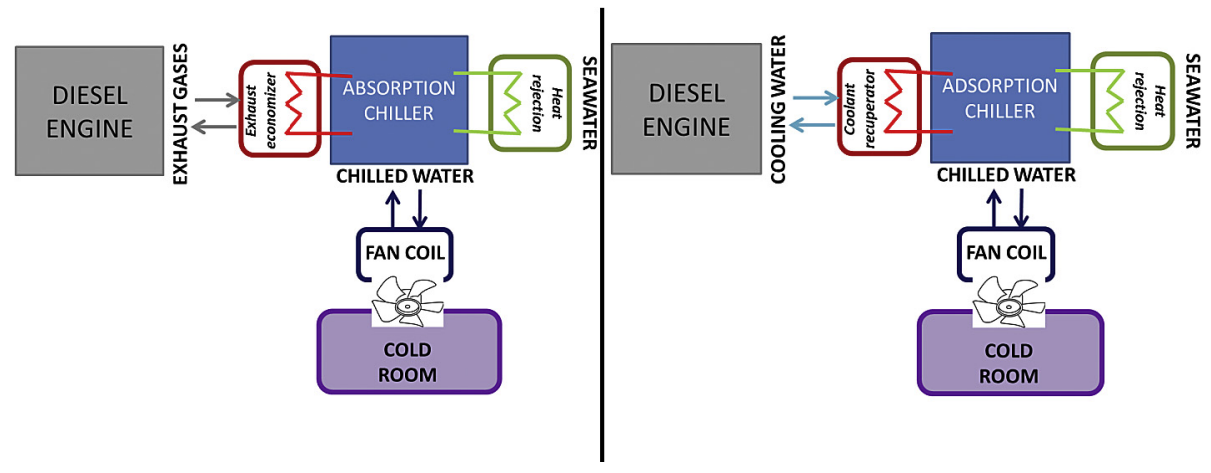

Fig. 1. Schematic layout of the proposed refrigeration systems. 
but its temporal distribution (influencing the peak power needed for refrigeration) is different. The two load profiles simulated are then:

1) Introduction of $100 \mathrm{~kg}$ of fish into the cell every $4 \mathrm{~h}$;

2) Constant introduction of $25 \mathrm{~kg}$ of fish into the cell every hour from 3.00 to 20.00 .

In order to calculate the cooling demand associated to such loads, data on the thermal characteristics (e.g. specific heat) of the fish have been taken from Ref. [21]. The temperature of the fish when it is introduced in the cold room has been considered equal to the average temperature of the surface water of Mediterranean Sea, while the target temperature for storage has been assumed equal to $0{ }^{\circ} \mathrm{C}$. Fig. 3 shows the resulting profiles used as the internal load input for the $40 \mathrm{~m}^{2}$ cold room. The typical route of vessels in the examined fleet is of about $24 \mathrm{~h}$, the vessel being unloaded each day. Then, also the load profiles have been distributed onto such tem-poral span.

\section{Modelling of the components}

For the simulation of the system, TRNSYS environment has been chosen, since it includes types with all the relevant components of HVAC and refrigeration systems [22]. Moreover, it allows performing dynamic simulations, thus considering the variable regime of the diesel engine and the variable cooling load due to the route of the vessel.

\subsection{Main engine}

As previously stated, the heat recovered from exhaust gases has been chosen as the driving medium for the absorption refrigerator. For this reason, the thermal energy available to sorption systems is tightly linked to the operation of the main engine and to the heat contained in the exhausts. The amounts of available and recoverable heat depend on the actual working regime of the main engine: the actual power output of the diesel engine affects both the temperature at which the exhaust gases exit from such component and their flow rate [23]. To derive such correlation, which has been used then as input in the mathematical modelling of the system, the data reported in Ref. [7] have been employed. The results are reported in Fig. 4 as a function of the part load ratio of the engine. This has been defined as the ratio between actual power output and rated power of the engine:

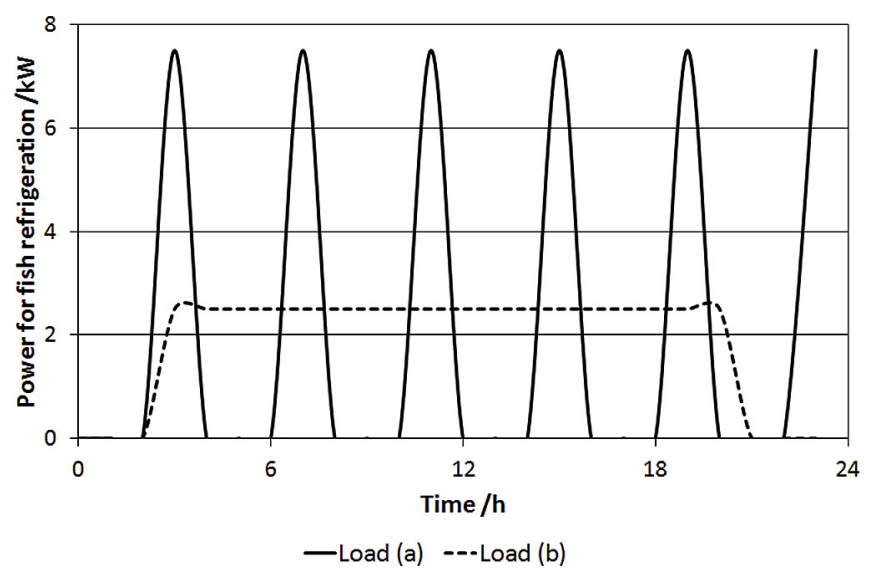

Fig. 3. The internal load scenarios due to the refrigeration of fish.
$P L R=\frac{P_{\text {actual }}}{P_{\text {rated }}}$

The equations reported in the charts, that show an accuracy of about $90 \%$, have then been implemented in TRNSYS, together with the engine utilization profile for a selected route, which is shown in Fig. 5. Such route has been modelled according to the typical daily navigation of Italian vessels. However, as will be discussed in the following sections, the obtained results can be generalised to a wider range of conditions.

For the adsorption system, instead, the driving circuit is realised through heat recovery from the cooling water system of the main engine. In this case, as reported for example in Ref. [24], an internal control of marine engines exists, that keeps the outlet temperature of the cooling system constant, and consequently a constant inlet at $80{ }^{\circ} \mathrm{C}$ has been considered, disregarding the PLR of the engine.

\subsection{Waste heat recovery system}

In order to operate the chillers, only waste heat recovered from the engine has been considered. Different approaches have been proposed in literature [25]. For example, in Ref. [26], where an adsorption chiller for the space conditioning of a car is proposed, the heat recovery system is composed of two heat exchangers, an economizer from the main engine and a second exchanger working as a generator for the chiller. Instead, in the present case, the waste heat system has been considered as a single heat exchanger:

- In the case of the absorption chiller, it serves as an economizer from the waste fumes of the engines. It is then a gas-to-liquid heat exchanger, using thermal oil as heat transfer fluid. The economizer is directly connected to the generator circuit of the chiller. The UA value of the heat exchanger, simulated by means of TRNSYS type 5 e, has been considered equal to $350 \mathrm{~W} / \mathrm{K}$ for an absorption chiller prototype of $15 \mathrm{~kW}_{\mathrm{c}}$.

- In the case of the adsorption chiller, the waste heat used for the regeneration of the adsorbent material is the cooling water of the main engine. Consequently, the recuperation system is made of a single water-to-water heat exchanger, modelled by means of type 5 e, with UA value of $8000 \mathrm{~W} / \mathrm{K}$ for an adsorption chiller prototype of $10 \mathrm{~kW}_{\mathrm{c}}$.

Type 5e of TRNSYS environment uses a $\varepsilon$-NTU approach: given the hot and cold side inlet temperatures and flow rates, the effectiveness is calculated for the user-selected value of the overall heat transfer coefficient and, consequently, the outlet temperatures in the primary and secondary circuit are calculated as well.

\subsection{Cold room}

Cold rooms, in the kind of vessels considered, are generally located below the main deck of the bridge. In the present work, the cold room has been modelled in TRNSYS by using TYPE 56. The walls of the cold room have been considered as a 3-layers structure: two layers in AISI 304 stainless steel (external and internal), with an insulation of polyurethane foam. The distribution system for cold water can be either a fan coil or a static cooling coil. Some pictures of the typical cold rooms in Sicilian fishing vessels, taken in Mazara del Vallo, are shown in Fig. 6. In Table 2, the main parameters employed for the structures and the refrigeration system of the cold room, are summarised. All the chosen parameters fit the data supplied by the manufacturers of the cold rooms for the existing fishing fleet in Sicily. A parametric analysis has been performed, with the aim of establishing the effect of external ambient 

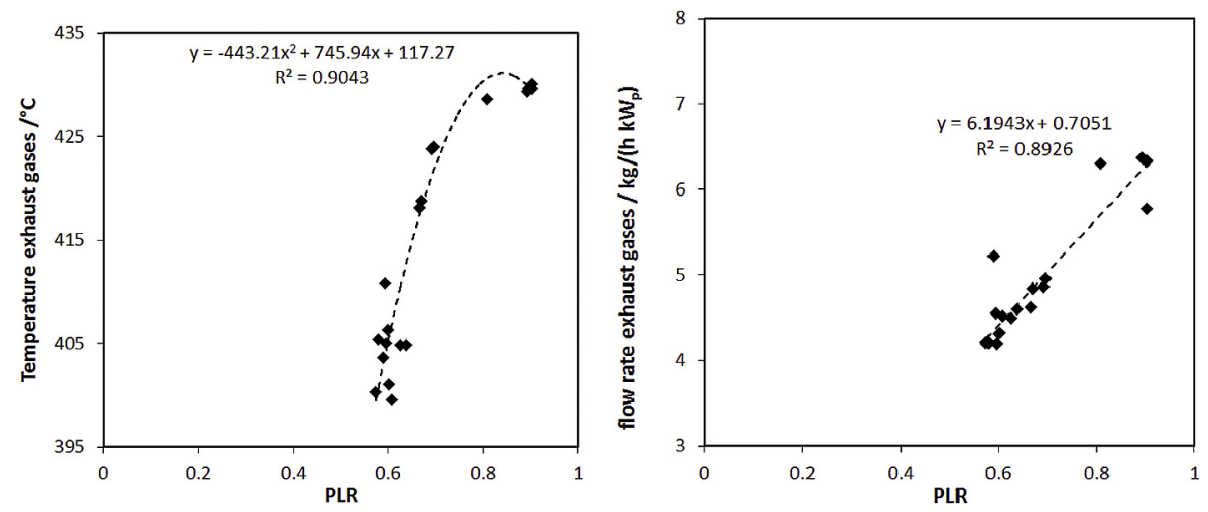

Fig. 4. Temperature and flow rate of exhaust gases as a function of PLR of the engine.

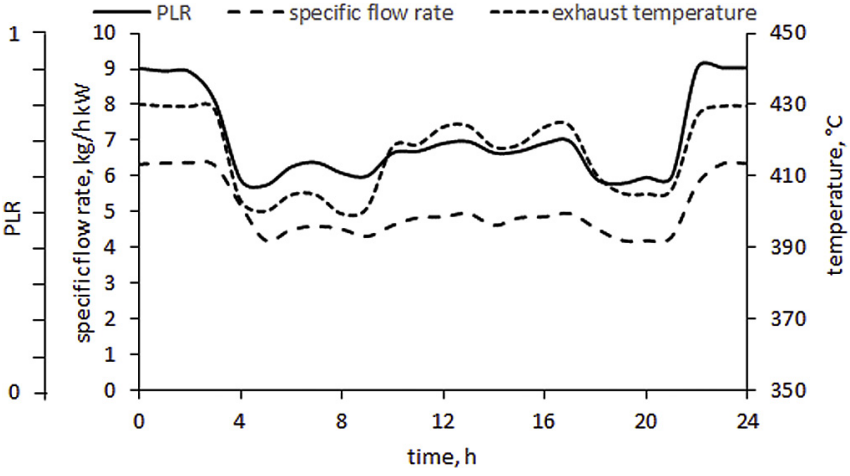

Fig. 5. Engine data profiles for the selected route.

temperature and solar radiation on the cooling load of the cell. Indeed, this represents an important issue, since such analysis allows establishing whether -and to what extent-external conditions influence the cold room. To this aim, only the base load of the room (with no internal gains due to the introduction of fishery) has been evaluated. The results of the parametric analysis are reported in Fig. 7: the difference in the cooling load required varying the external temperature from $10{ }^{\circ} \mathrm{C}$ to $35{ }^{\circ} \mathrm{C}$ is only around $0.4 \mathrm{~kW}$. Based on such considerations, the results of the following analysis, performed on a route in the area of Mazara del Vallo, are extendible to other climates.

\subsection{Compression chiller}

The reference system consists of a traditional vapour compression chiller, employing R422a as refrigerant. It has been simulated
Table 2

Main parameters for the modelled cold room.

\begin{tabular}{lll}
\hline Parameter & Unit & Value \\
\hline Thermal conductivity of AISI 304 & $\mathrm{W} / \mathrm{mK}$ & 16.2 \\
Thermal conductivity of polyurethane foam & $\mathrm{W} / \mathrm{mK}$ & 0.026 \\
Thickness of AISI 304 & $\mathrm{m}$ & $\begin{array}{l}0.002+0.002 \mathrm{~mm} \\
\text { (external and }\end{array}$ \\
& & $\begin{array}{l}\text { internal sides) } \\
\text { Thickness of polyurethane foam }\end{array}$ \\
Overall wall thermal conductivity & $\mathrm{m}$ & 0.08 \\
Inner avg. temperature & $\mathrm{W} / \mathrm{m}^{2} \mathrm{~K}$ & 0.477 \\
Air changes & ${ }^{\circ} \mathrm{C}$ & 2 \\
Inner maximum ventilation rate & $1 / \mathrm{h}$ & About 0 \\
Total volume & $\mathrm{kg} / \mathrm{h}$ & 5000 \\
W $\times \mathrm{D} \times \mathrm{H}$ & $\mathrm{m}{ }^{3}$ & 40 \\
Internal gains considered & $\mathrm{m}$ & $5 \times 3.4 \times 2.4$ \\
& - & Introduction of fish at \\
& & seawater temperature \\
\hline
\end{tabular}

with TYPE 666, by defining a performance map depending on chilled water temperature, cooling water temperature and part load ratio of the compressor. To this aim, data from technical sheets of a manufacturer have been implemented [27]. The rated power and COP are $10 \mathrm{~kW}$ and 4.0, respectively. TRNSYS solver reads the external temperatures and interpolates the data of the performance map in order to get the instant values (input power, heat transfer rates, output temperatures, $\mathrm{COP}$ ).

\subsection{Other components}

Apart from the engine, the cold room and the chillers, the main components of the refrigeration systems are the exchanger to recover heat from exhaust gases or cooling water, the exchanger for the cooling water of the sorption chillers and the circulator pumps.

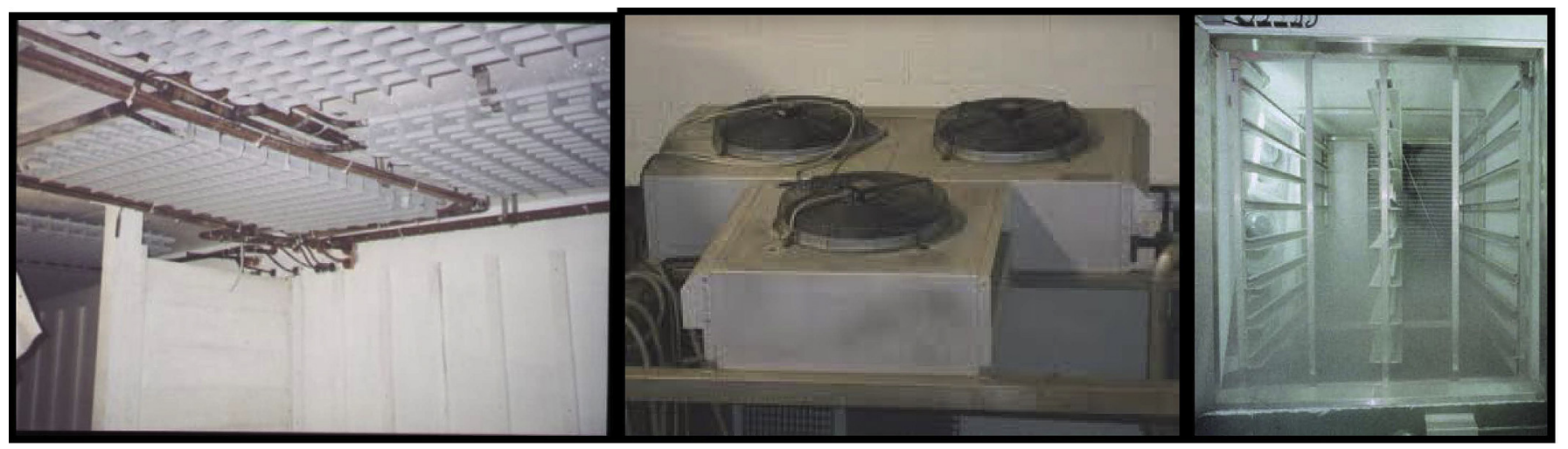

Fig. 6. Picture of some cold rooms and their components in Sicilian fishing vessels. 


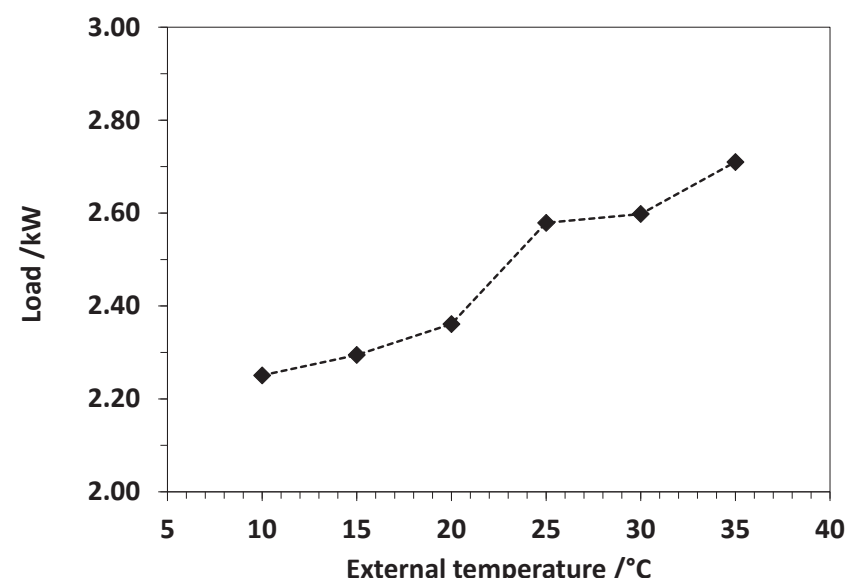

Fig. 7. Effect of ambient temperature on the cooling base-load of the cold room.

All the exchangers have been modelled using TRNSYS TYPE 5, by defining an overall heat transfer coefficient that takes into account both the heat transfer characteristics of the exchanger and its surface area, according to the values suggested in Ref. [28]. Instead, all the pumps in the system have been modelled as variable speed pumps (TYPE 3), even though the variable speed feature was used only for the adsorption based system. Finally, the system for cold water distribution in the cold room has been modelled with TYPE $508 \mathrm{~h}$. Type $508 \mathrm{~h}$ is a cooling coil with a fixed bypass fraction: when a user specified amount of air enters the device, a fraction of it passes through the coil, where it comes to saturation at the average of the entering and exiting water temperatures. The remaining volume of air bypasses the coil and is then remixed with the cooled dehumidified saturated air. TRNSYS solver, starting from the inlet temperatures of water and air and the flow rates of the fluids, calculates the amount of liquid, guesses an outlet temperature and iterates until the energy transferred from the air stream matches the energy transferred into the water stream.

The main parameters for TRNSYS simulations are reported in Table 3.

Control logic of the entire system has been carefully defined as well, since it is a crucial feature in the proper operation of thermally driven systems. For the system employing the adsorption chiller, focus of the control logic is the cooling demand of the cold room: according to such demand, the fan of the fan coil and the pump for the chilled water circuit of the chiller are turned on/off. Instead, the speed of the pumps on the cooling water and hot water circuits of the adsorption refrigerator are adjusted to keep the inlet constant, with a tolerance band of $\pm 2{ }^{\circ} \mathrm{C}$. For the system employing the ab-sorption chiller, the control strategy is more complicated due to the coupling between the exhaust gases and the diathermic oil loop. When the chilled water return temperature exceeds $+2{ }^{\circ} \mathrm{C}$ and the

Table 3

\begin{tabular}{lll} 
Table 3 & & \\
\hline Thefrapinetearameters for TRNSYS simulations. & Unit & Value \\
\hline Absorption unit, HT pump - maximum flow rate & $\mathrm{kg} / \mathrm{h}$ & 2000 \\
Absorption unit, MT pump - maximum flow rate & $\mathrm{kg} / \mathrm{h}$ & 4100 \\
Absorption unit, LT pump - maximum flow rate & $\mathrm{kg} / \mathrm{h}$ & 2700 \\
Adsorption unit, HT pump - maximum flow rate & $\mathrm{kg} / \mathrm{h}$ & 3000 \\
Adsorption unit, MT pump - maximum flow rate & $\mathrm{kg} / \mathrm{h}$ & 6000 \\
Adsorption unit, LT pump - maximum flow rate & $\mathrm{kg} / \mathrm{h}$ & 2700 \\
Efficiency of pumps, adsorption system & - & 0.50 \\
Efficiency of pumps, absorption system & - & 0.30 \\
Fan coil - maximum fluid flow rate & $\mathrm{kg} / \mathrm{h}$ & 3000 \\
Fan coil - maximum air flow rate & $\mathrm{kg} / \mathrm{h}$ & 5000 \\
\hline
\end{tabular}

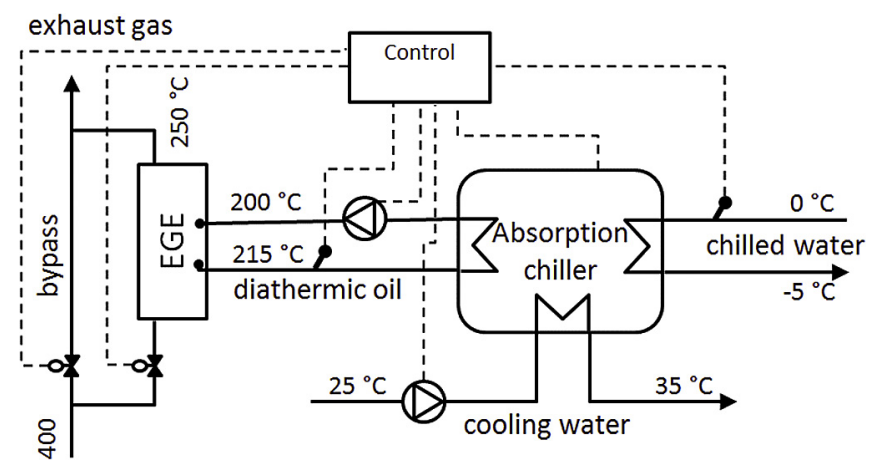

Fig. 8. Exhaust gas economizer

engine is above the minimum load that is necessary to drive the chiller, the exhaust economizer (EGE) is set in heat recovery mode and the diathermic oil pump is activated. The temperature in the oil loop increases and, when the threshold of $200{ }^{\circ} \mathrm{C}$ is reached, the solution pump of the chiller is started, along with the cooling water pump. The solution pump operates and the chiller generates refrigeration power according to the temperatures achieved in the three external heat exchangers. Since the maximum flow rate of the flue gas passing through the finned-tube heat exchanger is sized according to the chiller capacity, overheating of the oil circuit is normally not reached (for safety, a PID control keeps the oil temperature at $215{ }^{\circ} \mathrm{C}$ by acting on the flap valves). When the return temperature falls below $-2{ }^{\circ} \mathrm{C}$, the EGE is turned to bypass mode (see Fig. 8). In this way, the temperature of the oil loop decreases and when the lower threshold of $180^{\circ} \mathrm{C}$ is reached, the oil pump is turned off. The solution pump of the chiller and the cooling water pump are turned off after 5 min of inactivity of the oil pump.

\section{The developed sorption systems}

Since the aim of the present study is to assess the feasibility and the energy consumption of sorption systems for the production of a continuous refrigeration effect, experimental data previously measured by the authors on two real prototypal systems have been employed as input for TRNSYS simulations. Indeed, both the adsorption and the absorption refrigerators have been simulated using TRNSYS TYPE 909, where a performance map is introduced as input. TRNSYS solver then, according to the inlet conditions for the three loops of the chiller, interpolates between the data. In such a way, experimental conditions and performance can then be simulated to get a valid and accurate model.

\subsection{Adsorption refrigerator}

The adsorption refrigerator employed for the simulations is described in Ref. [29]: it is a lab-scale prototype employing activated carbon and ethanol as working pair. Such a choice, contrarily to the more common use of methanol $[13,30]$ has been preferred to avoid possible corrosion issues due to methanol and to avoid toxicity problems that do not arise in case of contact of working fluid with food. The system is characterised by double-bed architecture for the production of continuous cooling effect. The employed adsorbent is a commercial activated carbon in grains, with grain size of $0.4-0.7 \mathrm{~mm}$, packed into radiator-type aluminium heat exchangers. Condenser and evaporator are made each of a finned-tube heat exchanger, with copper fins and stainless steel tubes. Indeed, since the component is only in contact with the ethanol refrigerant and not directly exposed to marine environ-ment, such a choice guarantees sufficient corrosion resistance [31]. 
Volume and mass of the prototype are $142 \mathrm{dm}^{3}$ and $120 \mathrm{~kg}$, respectively. The prototype was tested at CNR-ITAE and the results employed to draw the map of performance, which represents TRNSYS input for the model of the adsorption chiller. A picture of the prototype during the tests at CNR-ITAE is shown in Fig. 9, while Fig. 10 shows an example of the performance of the system under different boundary conditions. For the complete definition of TRNSYS model, HT inlet temperatures in the range $80 / 90{ }^{\circ} \mathrm{C}$ have been used, as well as cooling water temperatures in the range 15/ $30^{\circ} \mathrm{C}$ and chilled water temperatures in the range $-5^{\circ} \mathrm{C} /+2^{\circ} \mathrm{C}$.

\subsection{Absorption refrigerator}

In this work, the performance of the absorption chiller is based on those of a prototype chiller that has been derived from of a gasfired commercial unit [32] and installed in a solar cooling plant [33]. The working pair is ammonia-water and the thermodynamic cycle is based on the GAX cycle concept, as described e.g. in Ref. [34]. The generator of the unit has been converted from gas fired to heat driven by means of a spiral baffled jacketed heat exchanger mounted around the bottom section of the generator, in order to promote heat transfer in counter flow configuration be-tween the driving heat transfer fluid (diathermic oil) and the ammonia-water mixture. In order to achieve good overall heat transfer values, the driving fluid flow rate shall be set to $3500 \mathrm{l} / \mathrm{h}$. At this flow rate, the pressure drop across the jacketed heat exchanger mounted around the generator is 1.0 bar. Pressure drops of 0.3 bar have been obtained for both the cooling water and the chilled water heat exchangers at their respective nominal flow rates. The auxil-iary energy consumed by the chiller for solution pump and control is of $350 \mathrm{~W}$. Based on these data, a performance map TRNSYS model has been parameterized. The model outputs (thermal COP and refrigeration capacity of the prototype) are shown in Fig. 11.

\section{Methodology}

The methodology followed is summarised in Fig. 12. The purpose of the analysis is threefold: at the beginning, an energy and environmental analysis has assessed the energy savings, both in terms of electric energy and fuel consumption, and the environmental benefits, in terms of avoided $\mathrm{CO}_{2}$ emissions, deriving from the application of sorption systems. The results have then been generalised by means of a sensitivity analysis based on the load demand for refrigeration and the actual characteristics of existing

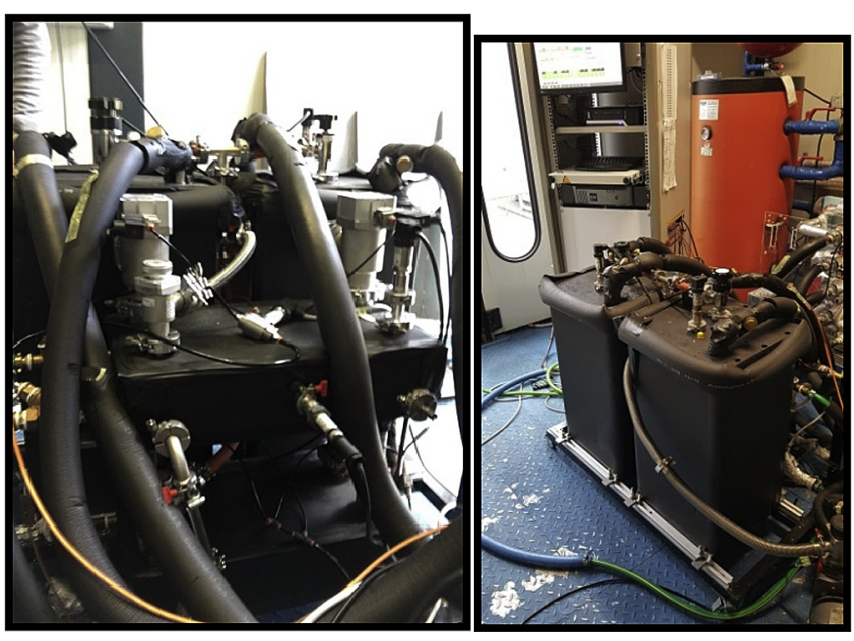

Fig. 9. The adsorption refrigerator developed at ITAE. systems. A payload analysis is proposed as well, with the aim of assessing the effect of the excess mass of the components of the thermal systems on the fuel consumption.

It is worth noticing that the main components of the system have been simulated using a performance-map approach, based either on experimental data (engine, sorption chillers) or datasheet from the producers (vapour compression chillers), that guarantees a good accuracy of the simulation. The remaining components are all based on well-established equations, such as the $\varepsilon$-NTU used for the heat exchangers. The validation of the various components can therefore represent a sufficient base for ensuring the adherence of the models to real systems that are optimally sized, installed and operated.

\subsection{Sizing of the sorption systems}

Both sorption systems used for the analysis have different sizes from the load demand of the cold room: the prototype of adsorption system has a nominal power of $300 \mathrm{~W}$-lower than the load requested-, the prototype of the absorption system is $15 \mathrm{~kW}$-higher than the load requested.

Then, for the modelling of the system, scaling of the systems is necessary. Indeed, for the power, mass and flow rates, a linear scaling function has been defined. Regarding the power output from the thermal chiller and its COP, TRNSYS type 909 is intrinsically built to fulfil such a need [22]: for each experimental point, the cooling capacity and COP are inserted as a fraction of the nominal values. Consequently, when scaling the system, it is sufficient to define the scaled nominal power and COP and the solver's routine will take that into account. For the mass and flow rates, a normalization procedure has been followed: for each parameter, the specific value for each $\mathrm{kW}$ of cooling output has been calculated from experimental data. The factor obtained has been used for the calculation of the scaled values, using an equation of the type:

$\delta=\frac{\delta_{\text {real }}}{P_{\text {real }}} P_{\text {desired }}$

where $\delta$ represents a generic parameter, $\mathrm{P}_{\text {real }}$ is the actual power of the prototype of the thermal system and $\mathrm{P}_{\text {desired }}$ is the scaled power.

The values of the ratio:

$\alpha=\frac{\delta_{\text {real }}}{P_{\text {real }}}$

for the various parameters are given in Table 4 .

It is worth noticing that, according to the scaling rules for engineering systems reported in Ref. [35], such linear scaling can actually underestimate the power density of the system and therefore safety conditions are respected.

\section{Results}

As previously discussed, not many examples exist in literature of analysis of sorption systems for on-board applications. Moreover, the majority of them focus on the thermodynamic aspect, especially in the coupling with the engine. Instead, in the present work, the main goal is to draw some general conclusions on the technical feasibility of such systems in a specific field of application, i.e. the refrigeration of fish. To this aim, the following sections will be mostly devoted to defining the advantages, in terms of spared fuel and GHG emissions, for the systems. Hence, the main parameters taken into account for the analysis are the amount of energy needed to drive the systems and the energy consumed by the refrigeration systems. 

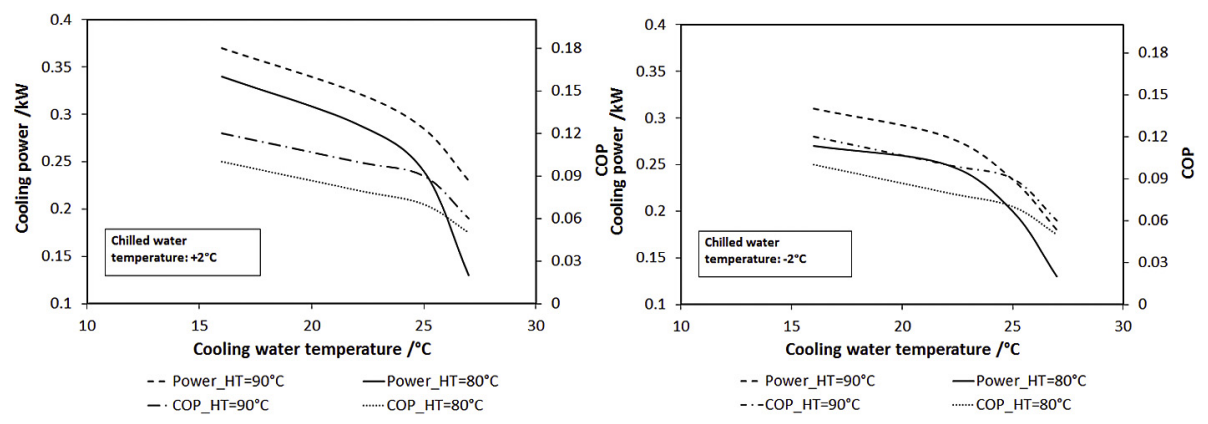

Fig. 10. Power and COP performance of adsorption refrigerator prototype used for the analysis.
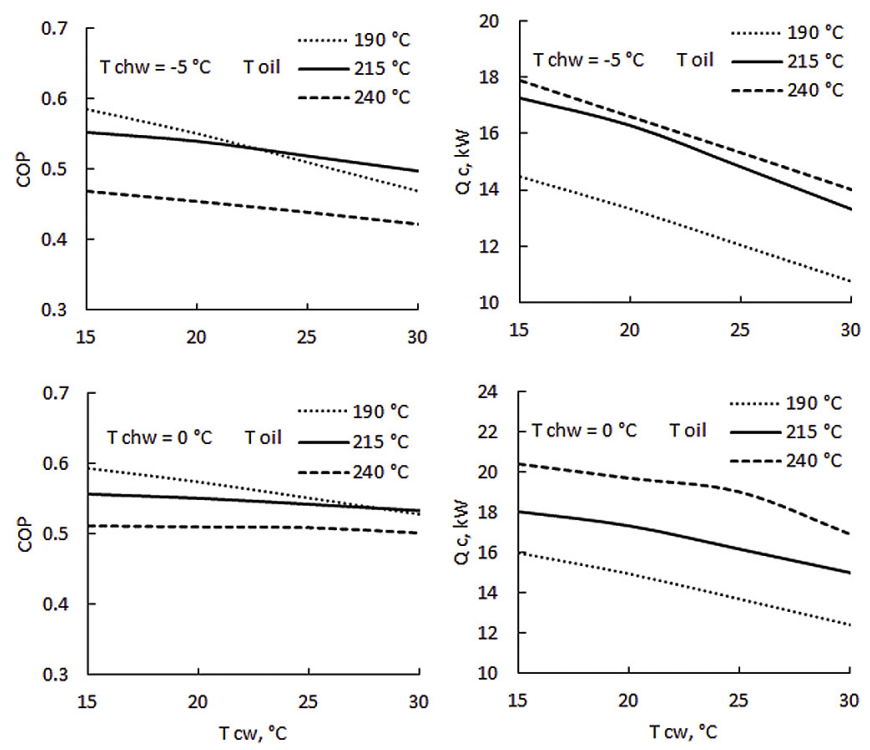

Fig. 11. Thermal COP and refrigeration capacity of the $15 \mathrm{~kW}$ prototype absorption refrigerator.

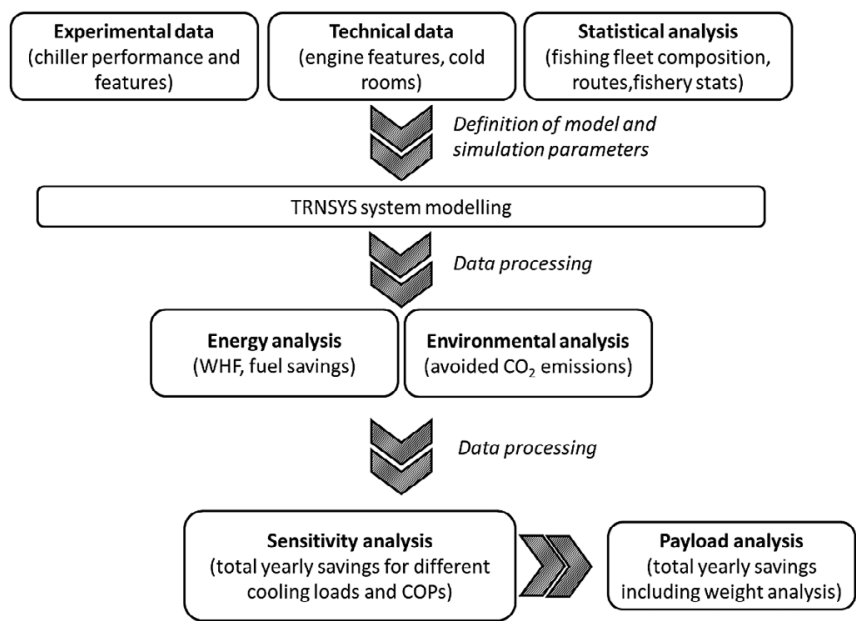

Fig. 12. Methodology.

\subsection{Energy analysis}

Prior to the energy savings analysis, the availability of waste heat, from jacket water coolant for the adsorption system and from exhaust gases for absorption one, has been verified, calculating the fraction of waste heat needed for driving the sorption system:

$W H F=\frac{E_{\text {driving.sorption }}}{E_{\text {max.waste heat }}}$

With waste heat energy calculated as the energy content of jacket water stream or exhaust gases for adsorption and absorption systems, respectively.

Electric energy savings with respect to the reference system can be calculated as:

$E E S=E_{\text {traditional }}-E_{\text {sorption }}$

where, for both cases, the energy consumptions are obtained by adding the consumptions of chiller and auxiliaries (the pumps in all the circuits).

Considering that electricity generation on board is obtained through a generator attached to the main engine, fuel savings can be calculated as:

$F S=\frac{E E S}{\eta_{\text {gen }} L H V_{\text {fuel }}}$

Moreover, the efficiency of the system has been calculated, in terms of thermal COP of the chiller and electric COP of the system.

The thermal COP of the chiller is defined as the useful effect provided by the chiller (i.e. the cooling power delivered to the distribution system) over the heat needed for its operation and provided by the waste heat recovery system:

$C O P_{\text {th }}=\frac{P_{\text {cooling }}}{P_{\text {heating }}}$

Instead, the electric COP of the system has been calculated as the ratio between the useful cooling effect provided by the chiller and the overall electric consumption of the chiller and the external circulator pumps:

$\mathrm{COP}_{\text {el }}=\frac{P_{\text {cooling }}}{E_{\text {el }, \text { total }}}$

The results of the analysis are summarised in Table 5, where the most relevant energy streams involved in the system are quantified, together with the thermal and electric COP. The difference in the electric consumptions between the two cases can be explained considering the control logic imposed, with on/off cycles, that do not allow for any smoothing of the capacity needed, as would happen if continuous production of cold had been implemented. Similar considerations can be done for the absorption unit: in this case, due to the higher efficiency of the system, electric COPs up to 14 have been reported. The same results can be better visualized by looking at the total amount of waste heat available used by the 
Table 4

Parameters for the scaling functions of the system.

\begin{tabular}{lll}
\hline Parameter & $\beta$-absorption & $\beta$ - adsorption \\
\hline UA- seawater/cooling water heat exchanger & $530 \mathrm{~W} /\left(\mathrm{K} \mathrm{kW}_{\mathrm{c}}\right)$ & $530 \mathrm{~W} /\left(\mathrm{K} \mathrm{kW}_{\mathrm{c}}\right)$ \\
UA-exhaust gas economizer & $23 \mathrm{~W} /\left(\mathrm{K} \mathrm{kW}_{\mathrm{c}}\right)$ & - \\
UA-engine cooling water heat exchanger & - & $800 \mathrm{~W} /\left(\mathrm{K} \mathrm{kW}_{\mathrm{c}}\right)$ \\
HT circuit flow rate & $205 \mathrm{~kg} /\left(\mathrm{h} \mathrm{kW}_{\mathrm{c}}\right)$ & $270 \mathrm{~kg} /(\mathrm{h} \mathrm{kW}$ \\
$\mathrm{c})$ \\
MT circuit flow rate & $530 \mathrm{~kg} /(\mathrm{h} \mathrm{kWc})$ & $500 \mathrm{~kg} /(\mathrm{h} \mathrm{kW}$ \\
$\mathrm{c})$ \\
LT circuit flow rate & $230 \mathrm{~kg} /\left(\mathrm{h} \mathrm{kW} \mathrm{hW}_{\mathrm{c}}\right)$ & $290 \mathrm{~kg} /(\mathrm{h} \mathrm{kW}$ \\
Auxiliaries power consumption & $23 \mathrm{~W} / \mathrm{kW}_{\mathrm{c}}$ & $13 \mathrm{~W} / \mathrm{kW}_{\mathrm{c}}$ \\
HT pump rated power consumption & $27.3 \mathrm{~W} / \mathrm{kW}_{\mathrm{c}}$ & $10 \mathrm{~W} / \mathrm{kW}_{\mathrm{c}}$ \\
MT pump rated power consumption & $20 \mathrm{~W} / \mathrm{kW}_{\mathrm{c}}$ & $20 \mathrm{~W} / \mathrm{kW}_{\mathrm{c}}$ \\
LT pump rated power consumption & $10 \mathrm{~W} / \mathrm{kW}_{\mathrm{c}}$ & $10 \mathrm{~W} / \mathrm{kW}_{\mathrm{c}}$ \\
Mass of the chiller & $26 \mathrm{~kg} / \mathrm{kW}_{\mathrm{c}}$ & $100 \mathrm{~kg} / \mathrm{kW}_{\mathrm{c}}$ \\
\hline
\end{tabular}

chillers. For the adsorption chiller, though the COP is very low, still less than $40 \%$ of recoverable waste heat is used. In the scenario considering the absorption chiller, that has a higher COP and is driven by exhaust gases from which more energy is recoverable, the fraction of heat employed is less than 10\%. Moreover, in Fig. 13, the electric consumption of all components, together with the per-centage of savings in replacing the traditional system with sorption ones, is represented. As visible, the amount of electrical energy saved is, in all scenarios, higher than $50 \%$.

Such considerations can be further detailed by looking at Fig. 14, where, for each load scenario, the contribution, in percentage, of each component to the overall primary energy consumption is shown. Clearly, in the case of the reference system, $75 \%$ of total energy consumption is due to the chiller operation. The difference between adsorption and absorption chiller is due to the presence, in the absorption chiller, of the electricity driven solution pump, which causes an additional consumption, while in the adsorption chiller the electric consumption is due only to internal valves and control circuits. Furthermore, the contribution of heat rejection is higher in the case of adsorption chiller, because of its lower thermal COP. Lastly, while the adsorption chiller requires a higher heat input, the diathermic oil circuit driving the absorption chiller re-quires, at parity of heat input, higher volume flow rates and pres-sure drops; such is the reason why the energy consumption of the HT circuit constitutes the highest share of the total for the absorption case.

\subsection{Environmental analysis}

Avoided $\mathrm{CO}_{2}$ emissions have been calculated taking into account both the direct emissions, due to the electricity consumption, and

Table 5

Results of energy analysis.

\begin{tabular}{lllll}
\hline & & Reference & Adsorption & Absorption \\
\hline Load profile "1" & & & & \\
Cold energy produced & $\mathrm{MWh} / \mathrm{y}$ & 10.6 & 10.60 & 10.6 \\
Waste heat needed & $\mathrm{MWh} / \mathrm{y}$ & - & 151.43 & 19.91 \\
Waste heat fraction & $\%$ & - & $15 \%$ & $4 \%$ \\
Electricity consumption & $\mathrm{MWh} / \mathrm{y}$ & 3.39 & 1.61 & 1.05 \\
Average COP & - & - & 0.07 & 0.55 \\
Average COP & - & 3.0 & 6.6 & 10.4 \\
Fuel savings & $\mathrm{kg} / \mathrm{y}$ & - & 570 & 1200 \\
Load profile "2" & & & & \\
Cold energy produced & $\mathrm{MWh} / \mathrm{y}$ & 10.6 & 10.6 & 10.6 \\
Waste heat needed & $\mathrm{MWh} / \mathrm{y}$ & - & 72.9 & 9.85 \\
Waste heat fraction & $\%$ & & $16 \%$ & $4 \%$ \\
Electricity consumption & $\mathrm{MWh} / \mathrm{y}$ & 2.73 & 0.90 & 0.71 \\
Average COP & - & - & 0.07 & 0.55 \\
Average COP & - & 0 & 11.8 & 14.9 \\
Fuel savings & $\mathrm{kg} / \mathrm{y}$ & - & 1480 & 1599 \\
\hline
\end{tabular}

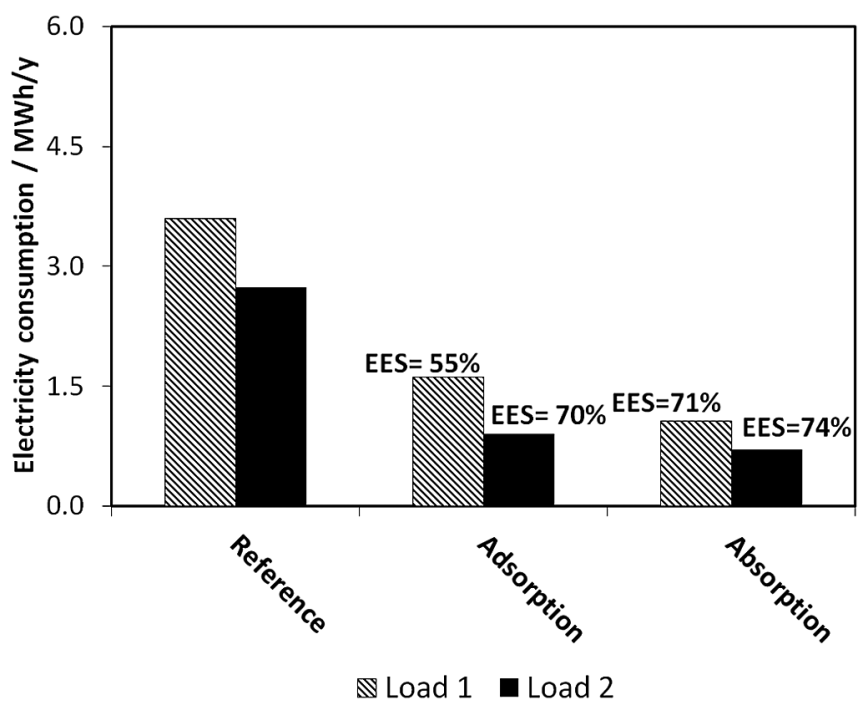

Fig. 13. Electricity consumption and energy savings in the different cases.

the indirect emissions due to leakage of refrigerants, as:

$$
\begin{aligned}
\Delta \mathrm{CO}_{2} & =\mathrm{CO}_{2, \text { reference }}-\mathrm{CO}_{2, \text { sorption }} \\
& =\eta_{\mathrm{CO}_{2}} \mathrm{EES}+m_{R 422 a} \cdot G W P_{R 422 a} \cdot \alpha
\end{aligned}
$$

The results are summarised in Table 6 , where the avoided emissions are shown. The national factor for $\mathrm{CO}_{2}$ emissions has been considered equal to $0.39 \mathrm{t}_{\mathrm{CO} 2} / \mathrm{MWh}$ [36]. The environmental benefits are quantified in more than $2 \mathrm{t} / \mathrm{y}$ for all the analysed scenarios.

\section{Sensitivity analysis}

In order to have a more complete overview of the feasibility of the analysed system and to generalise the study to a broader range of conditions, a sensitivity analysis has been performed. Specifically, the effect of two parameters has been investigated: the variation in the cooling demand for refrigeration, and the actual electric COP of the reference system.

Regarding the former parameter, it is worth noticing that the average load for the cold room is very low, even considering both the intrinsic load of the cold room and the load due to the introduction of fish. In particular, it is below the minimum size of the sorption systems available on the market [37]. Moreover, as shown in Table 5, the fuel savings achievable with such sizing of the system are low and the economic profitability of the installation is therefore questionable. A sensitivity analysis on the average cooling load has then been carried out. The leading criterion for the choice of the cooling demands to be simulated has been the utilization of waste heat. Hence, the maximum average cooling load simulated has been calculated as the one provided by the adsorption chiller (that requires a higher fraction of waste heat available) when $85 \%$ of the available waste heat is used. The average cooling demand satisfying such criterion is $12.5 \mathrm{~kW}$. For the increasing cooling load imposed in the cold room, the capacity of the sorption chillers, the flow rates in all the circuits and the masses of the refrigeration systems, including the auxiliaries and the components of the heat recovery system have been adjusted accordingly.

The results of the sensitivity analysis are shown in Fig. 15, in terms of annual fuel savings over the cooling load. In the same picture, the fraction of waste heat needed for each scenario has been represented. It is intuitive to comment that for higher cooling 


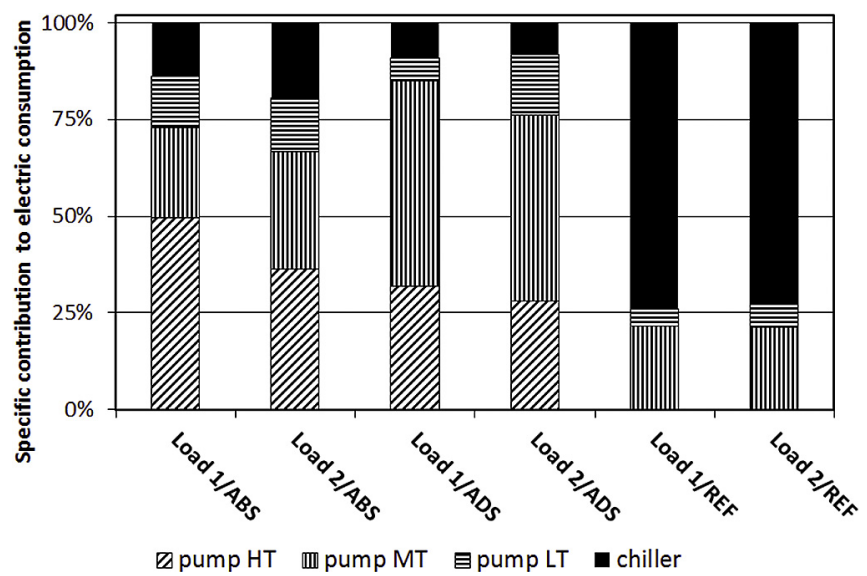

Fig. 14. Specific contributions of chillers and auxiliaries to total electric consumption.

loads, the amount of fuel saved is increased significantly, up to $13000 \mathrm{~kg} / \mathrm{y}$ for the absorption chiller and up to $10000 \mathrm{~kg} / \mathrm{y}$ for the adsorption chiller.

Another parameter considered for the sensitivity analysis is the actual efficiency of the reference system used for comparison. According to the simulations performed, the average electric COP of the vapour compression system applied for on-board refrigeration is 3.0. However, the general comment from Italian users is that the assembly of the refrigeration system, commonly made by local workshops (especially for the cold distribution system) negatively affects its efficiency. Consequently, the analysis on the effect of cooling load on fuel savings has been repeated by considering three different $\mathrm{COP}_{\mathrm{el}}$ of the reference system, namely, 1.5, 2.5 and 3.0. The results are shown in Fig. 16: considering a variation in the electric COP from 1.5 to 3.0 (the value from the simulations) the fuel savings achievable can be up to 7 times higher for the adsorption system, while for the absorption system they can be increased of about $350 \%$.

\subsection{Payload analysis}

Following the energy and sensitivity analysis, the effect of the mass increase due to the installation of waste-heat driven systems has to be evaluated. Indeed, despite a consistent fuel saving, due to the lower electricity consumption, the overall mass of the system (sorption chiller and waste heat recovery exchanger) is higher than the reference system and this could negatively affect the fuel consumption of the ship. To estimate such effect, the approach described in Ref. [10] has been followed. In particular, the analysis has been performed as follows: firstly, the extra power needed for propulsion due to the extra mass of the sorption systems has been calculated. Subsequently, the extra fuel consumption due to such mass has been considered.

The extra power needed to move a boat equipped with the proposed system, solely because of his mass, can be calculated as follows [10]:

Table 6

Results of the environmental analysis.

\begin{tabular}{lll}
\hline & $\mathrm{CO}_{2}$ emissions avoided $[\mathrm{t} / \mathrm{y}]$ & \\
\cline { 2 - 3 } & Adsorption & Absorption \\
\hline Load 1 & 2.24 & 2.42 \\
Load 2 & 3.22 & 3.30 \\
\hline
\end{tabular}

$\left.\frac{P_{s}}{P_{\text {ref }}}=1+\frac{\Delta_{s}-\Delta_{\text {ref }}}{\Delta_{\text {ref }}}\right)^{2 / 3}$

To define the values for simulations, an estimate of the mass of the main components of the different refrigeration systems is proposed in Table 7. The data have been taken from the technical sheets of producers for the compression chiller and the heat exchangers, while for the refrigerators the scaled values from the prototypes already presented have been employed.

The mass of the reference vessel has been considered equal to 400 tons. The fuel consumption of the engine has been taken from the datasheet supplied by the producer [24] as a function of the actual PLR load from Fig. 4.

The results of the analysis are shown in Fig. 17. In this figure, three curves have been plotted: the dotted curve and the dashed curve are the same of Fig. 15 and represent the fuel savings due to the utilization of the sorption systems for cooling loads in the cold room up to $12.5 \mathrm{~kW}$. The solid curve, instead, represents the extra fuel consumption due to the excess mass of the sorption systems. The intersection between such curve and the others represents the conditions under which an advantage in the choice of sorption system exists. The trends in the graph clearly indicates that the reduction in the mass of the thermal systems is a critical issue, because there is a strong dependence between the mass of the system and the extra fuel needed that can significantly reduce the benefits arising from the recovery of waste heat from the engine. For the analysed scenarios, the savings -in terms of fuel and GHG emissions - are still present and, especially for the higher cooling loads, consistent.

\section{Conclusions and future work}

In the present paper, a study regarding the feasibility of application of sorption cooling systems for on-board refrigeration of fish has been presented. Two different technologies have been compared: ammonia/water absorption and activated carbon/ ethanol adsorption. A dynamic analysis in TRNSYS environment, based on the experimental data from two prototypes using such sorption technologies has been performed. The whole heat recovery architecture has been simulated and the results reported, in terms of fuel savings and reduction of GHG emissions. In particular, for a cooling load typical of the Italian fishing fleet operating for $24 \mathrm{~h}$ before unloading, fuel savings up to $1600 \mathrm{~kg} / \mathrm{y}$ have been estimated, with 2-3 tons of $\mathrm{CO}_{2}$ emissions avoided annually. Subsequently, the cases of a higher cooling load and of a lower actual

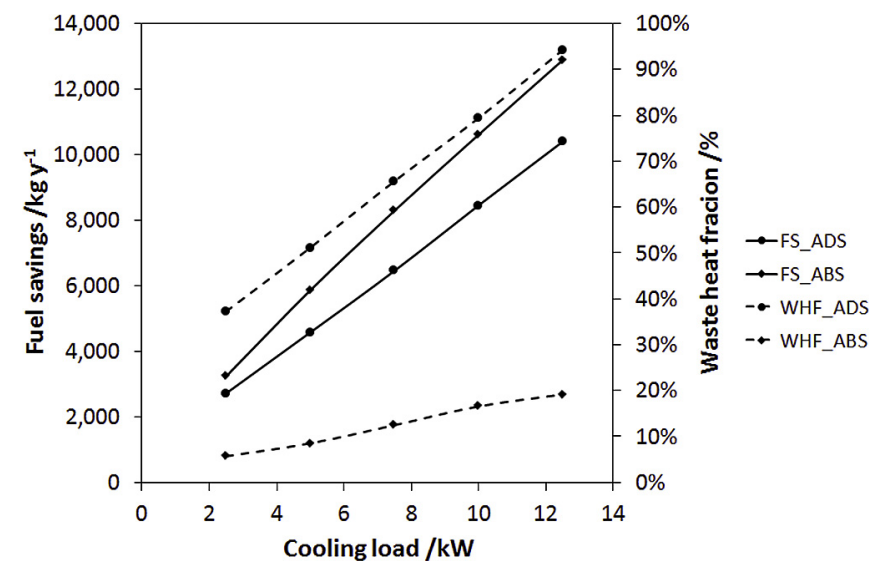

Fig. 15. Sensitivity analysis for variable cooling loads in the cold room. 


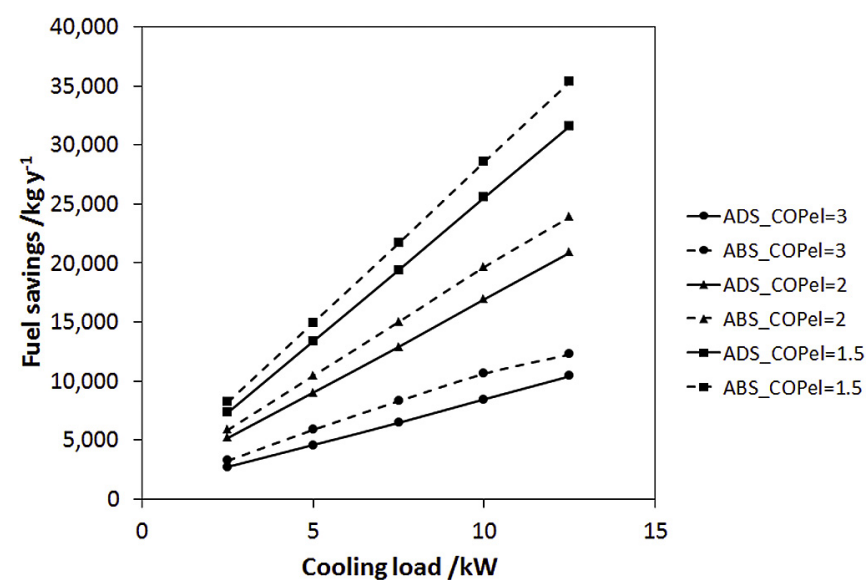

Fig. 16. Sensitivity analysis for variable cooling loads in the cold room and different electric COP of the reference system.

Table 7

Masses of the main components of the refrigeration systems.

\begin{tabular}{llll}
\hline Equipment & $\begin{array}{l}\text { Reference } \\
\text { system }\end{array}$ & $\begin{array}{l}\text { Adsorption } \\
\text { system }\end{array}$ & $\begin{array}{l}\text { Absorption } \\
\text { system }\end{array}$ \\
\hline $\begin{array}{l}\text { Refrigerator } \\
\text { Exhaust gas economizer }\end{array}$ & $20 \mathrm{~kg} / \mathrm{kW}_{\mathrm{c}}$ & $100 \mathrm{~kg} / \mathrm{kW}_{\mathrm{c}}$ & $26 \mathrm{~kg} / \mathrm{kW}_{\mathrm{c}}$ \\
$\begin{array}{l}\text { Coolant water } \\
\text { recuperator }\end{array}$ & - & - & $5.5 \mathrm{~kg} / \mathrm{kW}_{\mathrm{c}}$ \\
$\begin{array}{l}\text { Pumps } \\
\text { Total }\end{array}$ & $1 \mathrm{~kg} / \mathrm{kW}_{\mathrm{c}}$ & $10 \mathrm{~kg} / \mathrm{kW}_{\mathrm{c}}$ & $2 \mathrm{~kg} / \mathrm{kW}_{\mathrm{c}}$ \\
\hline
\end{tabular}

efficiency of the reference system have been analysed, highlighting that up to 7 times higher fuel savings can be achieved. Finally, a payload analysis has been realised, to take into account the extra fuel needed for the transportation of the higher-weighting sorption systems (including the heat recovery components).

However, despite the energetic and environmental benefits deriving from the use of a waste-heat powered system, economic convenience has to be proven before installation of such systems on fishing vessels. At the current state-of-the-art, no economic analysis has been performed because both the sorption systems investigated are at a prototypal state, especially the adsorption one that was a lab-scale prototype and therefore the uncertainty on cost figures would be too high.

For the practical application of sorption systems in the marine field, two aspects play a key role: the availability of properly sized chillers and the integration in a whole architecture devoted to heat recovery. Considering, for example, the examined cases, where the

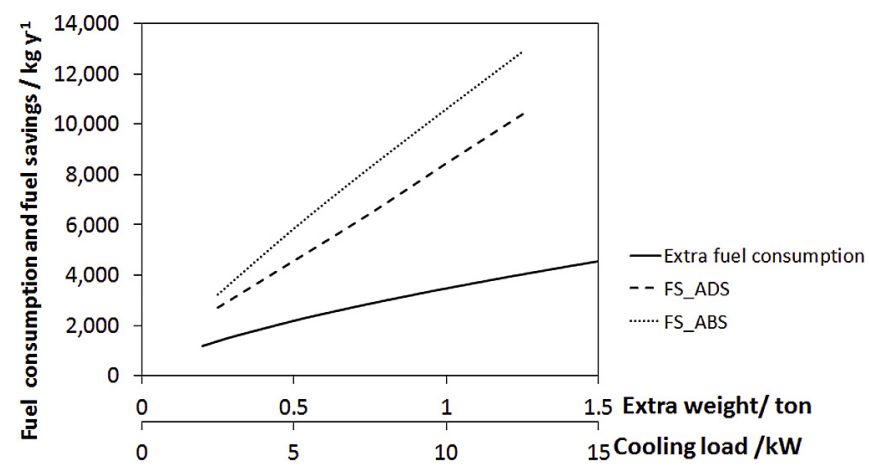

Fig. 17. Results of the payload analysis. cooling load needed ranges between 5 and $10 \mathrm{~kW}$, such demand is lower than the capacity of most absorption chillers available on the market today. This would lead to a lower efficiency of the chiller and higher payback times, because not the all of the capacity of the machine could be exploited. A future analysis should therefore evaluate the benefits achievable by the replacement of all four the refrigeration systems on-board by using only a sorption chiller.

Moreover, energy efficiency is an increasing central feature in the marine field [38], that requires a complex and multidisciplinary approach [39], in view also of stricter rules and energy policies $[40,41]$. In such a context, waste heat recovery has been the focus of growing attentions, with multiple possible applications [4], for example for electricity generation and air conditioning $[9,10]$. Should a waste heat recovery architecture been already available on board, the benefits in the replacement of traditional chillers with thermally driven ones would be even more marked, since no accessory investment cost for the installation of exhaust or coolant water recuperators would be needed.

\section{Acknowledgements}

The authors would like to thank Dr. Gioacchino Bono for the information about the refrigeration systems on-board of Sicilian fleet. The authors from ITAE acknowledge the support of Italian Flagship Project "RItMare".

\section{References}

[1] Third IMO GHG study. International Maritime Organization; 2014.

[2] Schwarz W, Rhiemeier J-M. The analysis of the emissions of fluorinated greenhouse gases from refrigeration and air conditioning equipment used in the transport sector other than road transport and options for reducing these emissions Maritime, Rail, and Aircraft Sector - final report. European Commission; 2 November 2007.

[3] Baldi F, Gabrielli C. A feasibility analysis of waste heat recovery systems for marine applications. Energy 2015;80:654-65.

[4] Shu G, Liang Y, Wei H, Tian H, Zhao J, Liu L. A review of waste heat recovery on two-stroke IC engine aboard ships. Renew Sustain Energy Rev 2013;19: 385-401.

[5] Bidini G, Maria F, Generosi M. Micro-cogeneration system for a small passenger vessel operating in a nature reserve. Appl Therm Eng 2005;25:851-65

[6] Choi In-Hwan, Lee Sangick, Seo Yutaek, Chang Daejun. Analysis and optimization of cascade Rankine cycle for liquefied natural gas cold energy recovery. Energy 2013;61:179-95.

[7] Fernandez-Seara J, Vales A, Vazquez M. Heat recovery system to power an onboard $\mathrm{NH} 3-\mathrm{H} 2 \mathrm{O}$ absorption refrigeration plant in trawler chiller fishing vessels. Appl Therm Eng 1998;18:1189-205.

[8] Ouadha A, El-Gotni Y. Integration of an ammonia-water absorption refrigeration system with a marine Diesel engine: a thermodynamic study. Procedia Comput Sci 2013;19:754-61.

[9] Cao T, Lee H, Hwang Y, Radermacher R, Chun HH. Performance investigation of engine waste heat powered absorption cycle cooling system for shipboard applications. Appl Therm Eng 2015;90:820-30.

[10] Cao T, Lee H, Hwang Y, Radermacher R, Chun HH. Modeling of waste heat powered energy system for container ships. Energy 2016;106:408-21.

[11] Ezgi C. Design and thermodynamic analysis of an $\mathrm{H} 2 \mathrm{O}-\mathrm{LiBr}$ AHP system for naval surface ship application. Int J Refrig 2014;48:153-65.

[12] Wang RZ, Xu ZY, Pan QW, Du S, Xia ZZ. Solar driven air conditioning and refrigeration systems corresponding to various heating source temperatures. Appl Energy 2016;169:846-56.

[13] Wang LW, Wu JY, Wang RZ, Xu YX, Wang SG. Experimental study of a solidified activated carbon/methanol adsorption ice maker. Appl Therm Eng 2003;23:1453-62.

[14] Wang LW, Wang RZ, Wu JY, Xia ZZ, Wang K. A new type adsorber for adsorption ice maker on fishing boats. Energy Convers Manag 2005;46: 2301-16.

[15] Shi Y, Chen G, Hong D. The performance analysis of a novel absorption refrigeration cycle used for waste heat with large temperature glide. Appl Therm Eng 2016;93:692-6.

[16] Sapienza A, Gullì G, Calabrese L, Palomba V, Frazzica A, Brancato V, et al. An innovative adsorptive chiller prototype based on 3 hybrid coated/granular adsorbers. Appl Energy 2016;179:929-38.

[17] Lu Z-, Wang RZ. Experimental performance study of sorption refrigerators driven by waste gases from fishing vessels diesel engine. Appl Energy 2016;174:224-31.

[18] N. Torquati, Lettura statistica della pesca italiana, http://www.rivieraoggi.it/ 
wp-content/uploads/2013/10/I-dati-della-pesca-sambenedettesedocumento-di-Nazzareno-Torquati.pdf last acccessed 22/12/2016.

[19] Ministero delle Politiche Agricole Alimentari e Forestali, Piano Strategico Nazionale, Luglio. 2007

[20] V. Palomba, A. Frazzica, A. Freni, G. Bono, F. Urbani, A. Galvagno, S. Freni, Design of a waste-heat powered refrigeration system for on-board applications, in Proceedings of.VI SEA-MED conference, http://www.grinavi.it/doc/ Atti_SEA-MED_2014.pdf.

[21] Johnston WA, Nicholson FJ, Roger A, Stroud GD. Freezing and refrigerated storage in fisheries. FAO fisheries technical paper - 340. Rome: FAO; 1994.

[22] TRNSYS 17: a transient system simulation program, Solar Energy Laborator$\mathrm{y}$, University of Wisconsin, Madison, USA.

[23] Wei He W, Wang S, Zhang X, Li Y, Lu C. Optimization design method of thermoelectric generator based on exhaust gas parameters for recovery of engine waste heat. Energy 2015;91:1-9.

[24] Wartsila, Diesel engine products datasheet, http://www.wartsila.com/ products/marine-oil-gas/engines-generating-sets/diesel-engines, last accessed 24/09/2016.

[25] Klemes JJ, Arsenyeva O, Kapustenko P, Tovazhnyanskyy L. Compact heat exchangers for energy transfer intensification: low grade heat and fouling mitigation. Boca Raton, FL, USA: CRC Press; 2015.

[26] Ali SA, Chakraborty A. Thermodynamic modelling and performance study of an engine waste heat driven adsorption cooling for automotive air-conditioning. Appl Therm Eng 2015;90:54-63.

[27] Daikin packaged water cooled chillers manual, version 04. 2012

[28] Coulson JM, Richardson JF. Chemical engineering, vol. 6. Oxford: Pergamon Press; 1993.

[29] Frazzica A, Palomba V, Dawoud B, Gullì G, Brancato V, Sapienza A, et al. Design, realization and testing of an adsorption refrigerator based on activated carbon/ethanol working pair. Appl Energy 2016;174:15-24.

[30] Wang LW, Wang RZ, Wu JY, Wang K, Wang SG. Adsorption ice makers for fishing boats driven by the exhaust heat from diesel engine: choice of adsorption pair. Energy Convers Manag 2004;45:2043-57.
[31] De Renzo DJ, editor. Corrosion materials resistance handbook 4th edition. NY: Noyes Data Corporation; 1985. ISBN 978-0-8155-1023-9.

[32] ROBUR Gas Absorption chillers, technical datasheet, http://www.robur.com/ downloads/2897/355/ROBUR_ABSO_EN_11_2016.pdf, last accessed 15/05/ 2017.

[33] Aprile M. Simulation study of an innovative solar absorption refrigeration system. Msc Thesis. Borlange, Sweden: Dalarna University; 2006.

[34] Aprile M, Scoccia R, Toppi T, Guerra M, Motta M. Modelling and experimental analysis of a GAX NH3-H2O gas-driven absorption heat pump. Int J Refrig 2016;66:145-55.

[35] Chakraborty S, editor. Mechanics over micro and nano scales. Springer; 2011. ISBN: 978-1-4419-9600-8.

[36] Taylor P, Lavagne D'Ortique O, Trudeau N, Francoueur M. Energy efficiency indicators for public electricity production from fossil fuels. IEA Information Paper. 2008. https://www.iea.org/publications/freepublications/publication/ En_Efficiency_Indicators.pdf.

[37] Allouhi A, Kousksou T, Jamil A, Bruel P, Mourad Y, Zeraouli Y. Solar driven cooling systems: an updated review. Renew Sustain Energy Rev 2015;44: 159-81.

[38] Rivera-Alvarez A, Coleman MJ, Ordonez JC. Ship weight reduction and efficiency enhancement through combined power cycles. Energy 2015;93: 521-33.

[39] Jafarzadeh S, Bouwer Utne I. A framework to bridge the energy efficiency gap in shipping. Energy 2014;69:603-12.

[40] International Maritime Organization. Guidelines on the method of calculation of the attained Energy Efficiency Design Index (EEDI) for new ships, resolution MEPC.212(63). 2012. last accessed: 10.03.2017, http://www.imo.org/en/ OurWork/Environment/PollutionPrevention/AirPollution/Documents/ 245(66).pdf.

[41] International Maritime Organization. Guidelines for the development of a ship energy efficiency management plan (SEEMP), resolution MEPC.213(63). 2012. last accessed: 10.03.2017, http://www.imo.org/en/OurWork/Environment/ PollutionPrevention/AirPollution/Documents/213(63).pdf. 